\title{
Isolation of Keratin from Waste Wool Using Hydrothermal Processes
}

\author{
Aleksandra Verdnik, ${ }^{1}$ Maja Čolnik, ${ }^{1}$ Željko Knez ${ }^{1,2}$ and Mojca Škerget ${ }^{1, \star}$ \\ ${ }^{1}$ University of Maribor, Faculty of Chemistry and Chemical Engineering, Smetanova 17, 2000 Maribor, Slovenia \\ ${ }^{2}$ University of Maribor, Faculty of Medicine, Taborska ulica 8, 2000 Maribor, Slovenia \\ *Corresponding author: E-mail: mojca.skerget@um.si
}

Received: $11-26-2020$

\begin{abstract}
The subcritical water (SubCW) extractions of waste wool to produce keratin were performed at temperatures of $150{ }^{\circ} \mathrm{C}$ to $250^{\circ} \mathrm{C}$ and at different reaction times between $5 \mathrm{~min}$ to $75 \mathrm{~min}$. The resulting proteins in the obtained products were confirmed with Fourier-transform infrared spectroscopy (FTIR). The molecular weight of the protein extracts was determined by using two different methods: with a polyacrylamide gel electrophoresis in the presence of sodium dodecyl sulphate (SDS-PAGE) and by using a gel permeation chromatography. The results show, that by using SubCW, keratin can be isolated from waste wool in very high yields, much higher than by other chemical methods. Maximal yield was achieved at $180^{\circ} \mathrm{C}$ and $60 \mathrm{~min}$ and it was $90.3 \%$. The molecular weight distributions of extracted proteins, which were generated from waste wool were between $14 \mathrm{kDa}$ and $4 \mathrm{kDa}$, what is comparable to the results obtained by other chemical methods.
\end{abstract}

Keywords: Waste wool; keratin; isolation; SubCW; gel permeation chromatography; SDS-PAGE electrophoresis.

\section{Introduction}

The growing concerns regarding the environmental pollution and the increasing demand for safe and sustainable materials are encouraging the search for green processing methods that would allow exploitation of natural resources and development of bio-based products. By-products of the textile and meat industries, such as wool, horns, hooves and feathers contain a large proportion of keratin., ${ }^{1,2}$ Keratin is a protein that has, due to its biodegradability and biocompatibility, recently become increasingly important. ${ }^{3}$ Wool is often used in textile industry due to its excellent mechanical properties. More than 2.5 million tons of wool is produced every year all over the world, where Australia, China, New Zeeland, Iran and Argentina represent five of the biggest producers of wool. ${ }^{4}$ The problem is that during the shearing and weaving processes as well as by processing in abattoirs also a considerable amount of wool waste is generated. Wool contains up to $95 \%$ of pure keratin, which is an important secondary product. ${ }^{5}$ In addition to proteins, wool contains small proportion of lipids, mineral salts, nucleic acid residues and carbohydrates. ${ }^{2}$ Keratin has an extremely high potential to be used for the development of new products in the pharmaceutical, medical, cosmetic and biotechnology industries. Keratin from wool can be used for several forms of gels, microfibres, films, sponges, bulk materials, in wound healing, drug delivery, tissue engineering and medical devices. ${ }^{1,4,6,7}$

For the extraction of keratin from natural by-products different methods were used: reduction, oxidation, microwave radiation, sulfitolysis, alkaline extraction, ionic liquids and use of enzymes. ${ }^{8,9}$ The disadvantage of these methods is that organic solvents and harmful chemicals are used, that could disrupt the structure of keratin and consequently have a negative influence on keratin properties. Organic solvents are expensive, toxic and non-renewable and pollute our environment. $6,8,10$

Recently, subcritical water (SubCW) has been increasingly used as a green medium for the extraction of value-added compounds from various materials, as it has many beneficial properties compared to other organic solvents. ${ }^{11}$ SubCW is known as hot water under pressure with the critical point at $374{ }^{\circ} \mathrm{C}$ and 221 bar. ${ }^{12,13}$ Under these conditions, the ionic product, diffusivity and thermal conductivity of water increase. ${ }^{11,14-16}$ The advantages of the methods where SubCW is used as a medium are that they are performed rapidly and selectively without a catalyst, ${ }^{17}$ 
give high yields and high purity of products and water is easily removed from the decomposition products. ${ }^{18,19}$

SubCW was used for hydrolysis of biomass waste (fish waste, chicken waste, hair and feathers), to produce amino acids. ${ }^{20}$ Isolation of keratin from waste wool with SubCW has not yet been published. Until now, superheated water ${ }^{9}$ and steam explosion ${ }^{21}$ have been used for the isolation of keratin from wool and the yields of keratin were quite low (up to $30 \%$ ). ${ }^{9,21}$

The aim of this study was the development of Sub$\mathrm{CW}$ isolation process of protein keratin from waste wool and to evaluate the performance of the process regarding the yield and molecular weight of the produced protein. The protein extracts were characterized with SDS-PAGE electrophoresis, gel permeation chromatography and FTIR analysis and new data about the molecular weight distribution of the keratin, isolated from wool with SubCW are presented.

\section{Experimental}

\section{1. Materials}

The waste wool of white traditional Slovenian sheep was kindly donated by local sheep farm. Trizma ${ }^{\circledast}$ base, sodium dodecyl sulfate, ammonium persulfate, glycine, methanol, 2-propanol, bovine serum albumin, trypsin, hydrochloric acid, dextran blue and Sephadex G-100 were supplied by Sigma-Aldrich. Coomassie brilliant blue G-250, sodium chloride, potassium chloride, disodium phosphate, potassium phosphate, monobasic, methylene blue and potassium chloride were supplied by Merck. Acetic acid was supplied by J.T.Baker. Lonza ${ }^{\text {tw }}$ ProSieve $e^{\text {tw }}$ protein marker was supplied by Fisher Scientific. 3X blue stained deposition buffer for SDS-PAGE electrophoresis and dithiothreitol were supplied by BioLabs Inc.

\section{2. Isolation of Keratin from Waste Wool with SubCW}

The high pressure and high temperature batch reactor (series 4740 Stainless Steel, Parr Instruments, Moline, $\mathrm{IL}$, USA) was filled with $2 \mathrm{~g}$ of raw wool and $40 \mathrm{~mL}$ of distilled water. The ratio of solvent to wool was $20 \mathrm{~mL} / \mathrm{g}$. The filled reactor was purged three times with an inert nitrogen gas $\left(\mathrm{N}_{2}\right)$ and the pressure in the reactor was set to 20 bar. The reactor was wrapped with a heating wire and

Table 1. SubCW reaction conditions

\begin{tabular}{cc}
\hline Temperature & Reaction time \\
\hline $150^{\circ} \mathrm{C}$ & $5 \mathrm{~min}, 15 \mathrm{~min}, 30 \mathrm{~min}, 60 \mathrm{~min}$ \\
$180^{\circ} \mathrm{C}$ & $5 \mathrm{~min}, 15 \mathrm{~min}, 30 \mathrm{~min}, 60 \mathrm{~min}, 75 \mathrm{~min}$ \\
$200^{\circ} \mathrm{C}$ & $5 \mathrm{~min}, 15 \mathrm{~min}, 30 \mathrm{~min}, 60 \mathrm{~min}$ \\
$250^{\circ} \mathrm{C}$ & $5 \mathrm{~min}, 15 \mathrm{~min}, 30 \mathrm{~min}, 60 \mathrm{~min}$ \\
\hline
\end{tabular}

glass wool in order to prevent heat losses. The reactions were carried out at different temperatures and different reaction times, as shown in Table 1. After the extraction, the reactor was rapidly cooled down.

The post reaction mixture was filtered by vacuum permeation and the products were collected in the forms of aqueous solution and solid residue.

A portion of the aqueous solution $(2 \mathrm{~mL})$ was evaporated using a rotary evaporator to determine the yield of extracted keratin. The yield of keratin was calculated by the equation 1, where the initial mass of wool $\left(m_{\text {wool }}\right)$, mass of extracted products ( $\left.m_{\text {products }}\right)$ and a percent of keratin (95\%) in wool $(w)$ were considered. The yields of keratin were calculated on assumption, that wool contains $95 \%$ of keratin.

$$
\eta_{\text {keratin }}=\frac{m_{\text {products }}}{w \cdot m_{\text {wool }}} \cdot 100
$$

The remaining aqueous solution was stored in the freezer for further analysis.

\section{3. Fourier Transformed Infrared Spectroscopy (FTIR)}

The presence of functional groups characteristic of the extracted keratin (amide A, amide I, amide II, amide III) was confirmed using the technique of attenuated total reflection of infrared spectroscopy by Fourier transform (ATR-FTIR) in the wavelength range of $4000 \mathrm{~cm}^{-1}$ and $400 \mathrm{~cm}^{-1}$. The data were analyzed with the high-performance IR solution software. ${ }^{9}$

\section{4. Gel Permeation Chromatography}

The molecular weight of extracted proteins was determined with gel permeation chromatography. For the preparation of stationary phase, 5\% Sephadex G-100 gel was dissolved into deionized water and incubated at $95^{\circ} \mathrm{C}$ for $5 \mathrm{~h}$. Cooled Sephadex-G 100 was transferred into the glass separation column. $0.1 \mathrm{M}$ phosphate buffered saline (PBS) at $\mathrm{pH}=7.2$ as the mobile phase were used.

The molecular weight determination of extracted proteins was done by comparing the ratio of $\mathrm{V}_{\mathrm{e}} / \mathrm{V}_{0}$ for the sample protein and the $\mathrm{V}_{\mathrm{e}} / \mathrm{V}_{0}$ of protein standards of known molecular weight, where $V_{e}$ is the elution volume of standard protein and $\mathrm{V}_{0}$ is the void volume. ${ }^{22,23}$ The $\mathrm{V}_{0}$ of a glass separation column is based on the volume of effluent required for the elution of $0.2 \%$ blue dextran (large molecule). The calibration curve was prepared based on the standard proteins with already known molecular weights in the rage from 66000-360 Da. (Table 2).

The calibration curve of standards (equation 2) represents the dependence of the logarithm of the molecular weight $(\log \mathrm{M})$ on the ratio between the elution volume and the void volume of the column: 


$$
\log (M)=\frac{V_{e}}{V_{0}} \cdot k+n
$$

where $M$ is a molecular weight of keratin, $V_{\mathrm{e}}$ elution volume, $V_{0}$ void volume of column $(27 \mathrm{~mL}), k$ inclination of the curve and $n$ section on the y axis. ${ }^{22,23}$

Table 2. Molecular weights of standards

\begin{tabular}{cc}
\hline Standard protein & Molecular weight (Da) \\
\hline bovine serum albumin (BSA) & 66000 \\
trypsin & 23800 \\
methylene blue & 360 \\
\hline
\end{tabular}

Based on the equation 2 and elution volume of individual samples of isolated keratin the molecular weight of keratin was calculated.

In order to determine the elution volume of standards and samples, $1.4 \mathrm{~mL}$ of standards or sample solutions were loaded at the top of the column, the valve at the bottom was opened and the fractions of $1.5 \mathrm{~mL}$ were taken. The mobile phase (PBS buffer) was added at the top of the column throughout the experiment. The absorbance of the obtained fractions was measured by UV-Vis spectrophotometer at a wavelength of $280 \mathrm{~nm} .^{23}$ The fraction with the highest absorbance represented the elution volume of an individual sample or standard.

\section{5. SDS-PAGE Electrophoresis}

The molecular weight of the extracted keratin was determined by the SDS-PAGE gel electrophoresis. For the protein separation acrylamide/bisacrylamide (Acryl/Bis) separation gel with $1.5 \mathrm{M}$ Tris- $\mathrm{HCl}$ buffer at $\mathrm{pH} 8.8$ and $6 \%$ Acryl/Bis stacking gel with $0.5 \mathrm{M}$ Tris $\mathrm{HCl}$ buffer at $\mathrm{pH} 6.8$ were prepared. $20 \mu \mathrm{L}$ of extracted keratin sample was added to $20 \mu \mathrm{L}$ of loading buffer (mixture of SDS Blue Loading Buffer and dithiothreitol (DTT)). All prepared samples were incubated at $95^{\circ} \mathrm{C}$ for 3-5 min and then centrifugated at $10,000 \mathrm{rpm}$ for $2 \mathrm{~min}$. Afterwards, $10 \mu \mathrm{L}$ of sample and protein marker (mixture of highly purified proteins with molecular weights from 4.6 to $300 \mathrm{kDa}$ ) were pipetted from the bottom of the vial and transferred into the bottom of the gel wells. The electrophoresis was run at $150 \mathrm{~V}$ for $90 \mathrm{~min}$ with tris-glycine-SDS running buffer ( $\mathrm{pH} 8.3$ ).

After electrophoresis, the gels well were washed with deionized water and colored with Coomassie blue, methanol and acetic acid water mixture. Then, the gels were discolored with methanol, acetic acid water mixture. After that all gels were dried on the filter paper with a vacuum pump.

The gels were analysed by using ImageJ free software, which was based on the calibration curve of the protein marker, where the distances ( $d$, in pixels) from the boundary between the entry and separation gel to the protein marker were measured. The calibration curve observes the dependence of $\log M$ on the distance (d). ${ }^{8}$

\section{Results and Discussion}

\section{1. Influence of Temperature and Reaction Time on Keratin Yield}

The yield of keratin in the reaction mixture is affected by temperature and reaction time as it is shown in Table 3. At the low temperature of $150{ }^{\circ} \mathrm{C}$ and at short reaction times from 5-30 min the yield of keratin was the lowest and it was only between $1 \%$ and $26 \%$. As can be seen from Figure 1 at these conditions also the highest amount of wool residue was found. Rajabinejad et al. ${ }^{9}$ reported about similar yield of keratin (31\%) obtained from wool with superheated water in a microwave at $170{ }^{\circ} \mathrm{C}$ and $30 \mathrm{~min}$. In the present work however, by increasing the temperature to $180^{\circ} \mathrm{C}$, a much higher content of keratin in the liquid product was gained. The maximum yield of keratin $(90.3 \%)$ was achieved at the temperature of $180^{\circ} \mathrm{C}$ and reaction time of $60 \mathrm{~min}$. Generally, the results show, that with increasing the temperature and prolonging the reaction time, the yield of keratin first increases and reaches a maximum and then it started to decrease. Namely, the high temperatures probably caused further decomposition of keratin to oligomers and free amino acids. ${ }^{9}$

Table 3. Yield of extracted keratin from waste wool with SubCW.

\begin{tabular}{rcccc}
\hline $\boldsymbol{t}$ (min) & $\begin{array}{c}\boldsymbol{T}=\mathbf{1 5 0}{ }^{\circ} \mathbf{C} \\
\eta_{\text {keratin }}(\%)\end{array}$ & $\begin{array}{c}\boldsymbol{T}=\mathbf{1 8 0}{ }^{\circ} \mathbf{C} \\
\eta_{\text {keratin }}(\%)\end{array}$ & $\begin{array}{c}T=200{ }^{\circ} \mathbf{C} \\
\eta_{\text {keratin }}(\%)\end{array}$ & $\begin{array}{c}\boldsymbol{T}=\mathbf{2 5 0}{ }^{\circ} \mathbf{C} \\
\eta_{\text {keratin }}(\%)\end{array}$ \\
\hline $\mathbf{5}$ & 1.7 & 23.8 & 73.0 & 73.3 \\
$\mathbf{1 5}$ & 5.4 & 57.9 & 81.1 & 75.3 \\
$\mathbf{3 0}$ & 16.1 & 71.4 & 87.6 & 80.5 \\
$\mathbf{6 0}$ & 25.6 & 90.3 & 86.0 & 63.2 \\
$\mathbf{7 5}$ & $/$ & 73.6 & $/$ & $/$ \\
\hline
\end{tabular}
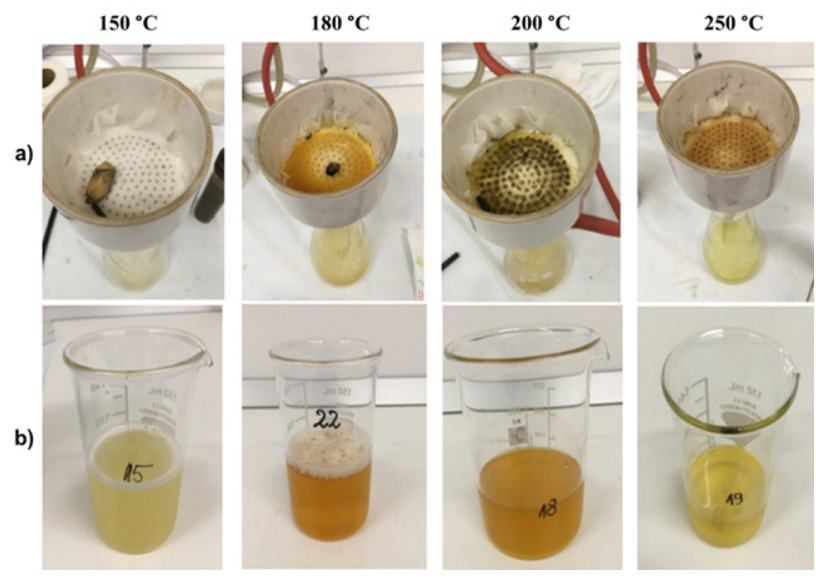

Figure 1. Reaction products at $150^{\circ} \mathrm{C}, 180^{\circ} \mathrm{C}, 200^{\circ} \mathrm{C}$ and $250{ }^{\circ} \mathrm{C}$ at the reaction time (60 $\mathrm{min})$; a) wool residues after filtration, b) liquid reaction product. 
Furthermore, the differences in concentration of keratin in aqueous solutions obtained at different operating parameters are also visible by the color of the liquid product (Figure 1). The color of the aqueous solutions changed from a very pale yellow colored solutions obtained at the lowest and the highest temperatures $\left(150{ }^{\circ} \mathrm{C}\right.$, $250{ }^{\circ} \mathrm{C}$ ) to an intense yellow colored solution obtained at middle temperatures $\left(180{ }^{\circ} \mathrm{C}\right.$ and $\left.200^{\circ} \mathrm{C}\right)$ where the yield of keratin was near or at the maximum.

\section{2. FTIR Analysis of Isolated Keratin}

In order to characterize the extracted keratin obtained from waste wool in SubCW at $180^{\circ} \mathrm{C}$ and $60 \mathrm{~min}$, FT-IR spectra were recorded. The infrared absorption spectra show characteristic absorption bands attributed to the peptide bonds. ${ }^{24}$

In Figure 2, the major peaks represent peptide bonds characteristic for amides: amide A, amide I, amide II, amide III). Amide A peak at $3230 \mathrm{~cm}^{-1}$ represents specific absorption bands for $\mathrm{N}-\mathrm{H}$ bond while peak at $1635 \mathrm{~cm}^{-1}$ (Amide I) is related to the $\mathrm{C}=\mathrm{O}$ stretching vibration. Amide II (between $1480 \mathrm{~cm}^{-1}$ and $1580 \mathrm{~cm}^{-1}$ ) shows elongation of $\mathrm{C}-\mathrm{N}$ bond and bending of $\mathrm{N}-\mathrm{H}$ functional groups, while amide III at wavelength $1242 \mathrm{~cm}^{-1}$ is a combination of $\mathrm{N}-\mathrm{H}, \mathrm{C}-\mathrm{N}$ and $\mathrm{C}=\mathrm{O}$ groups. Peaks that appear in the range between $2800 \mathrm{~cm}^{-1}$ and $3000 \mathrm{~cm}^{-1}$ are attrib- uted to the methylene stretching vibrations of the $\mathrm{CH}$, $\mathrm{CH}_{2}$ and $\mathrm{CH}_{3}$ functional groups. ${ }^{24}$

\section{2. Molecular Weight of Isolated Keratin}

The determination of the molecular weight of keratin with SDS-PAGE electrophoresis was done based on the calibration curve of protein standards (Figure 3) and by the elution of standards with known molecular weight

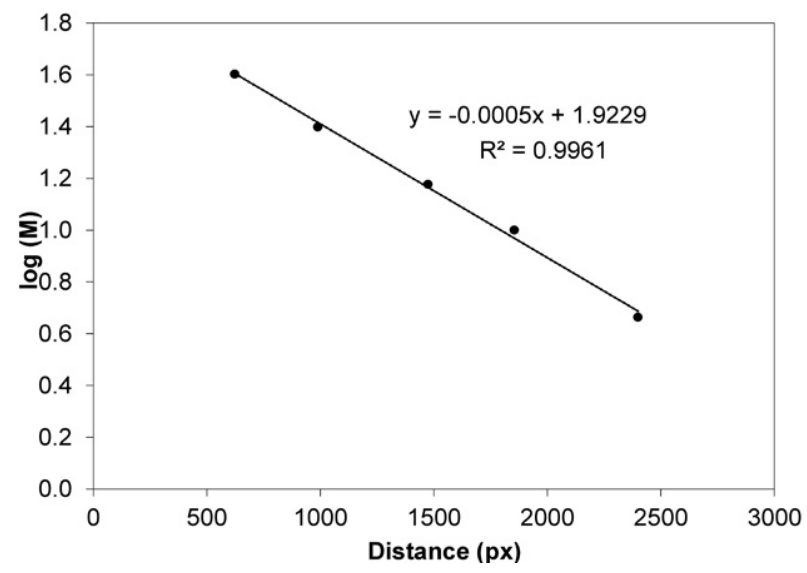

Figure 3. Standard curve of molecular weight markers using SDSPAGE electrophoresis for molecular weight estimation of keratin samples, which are obtained by hydrothermal degradation of waste wool at $180^{\circ} \mathrm{C}$.

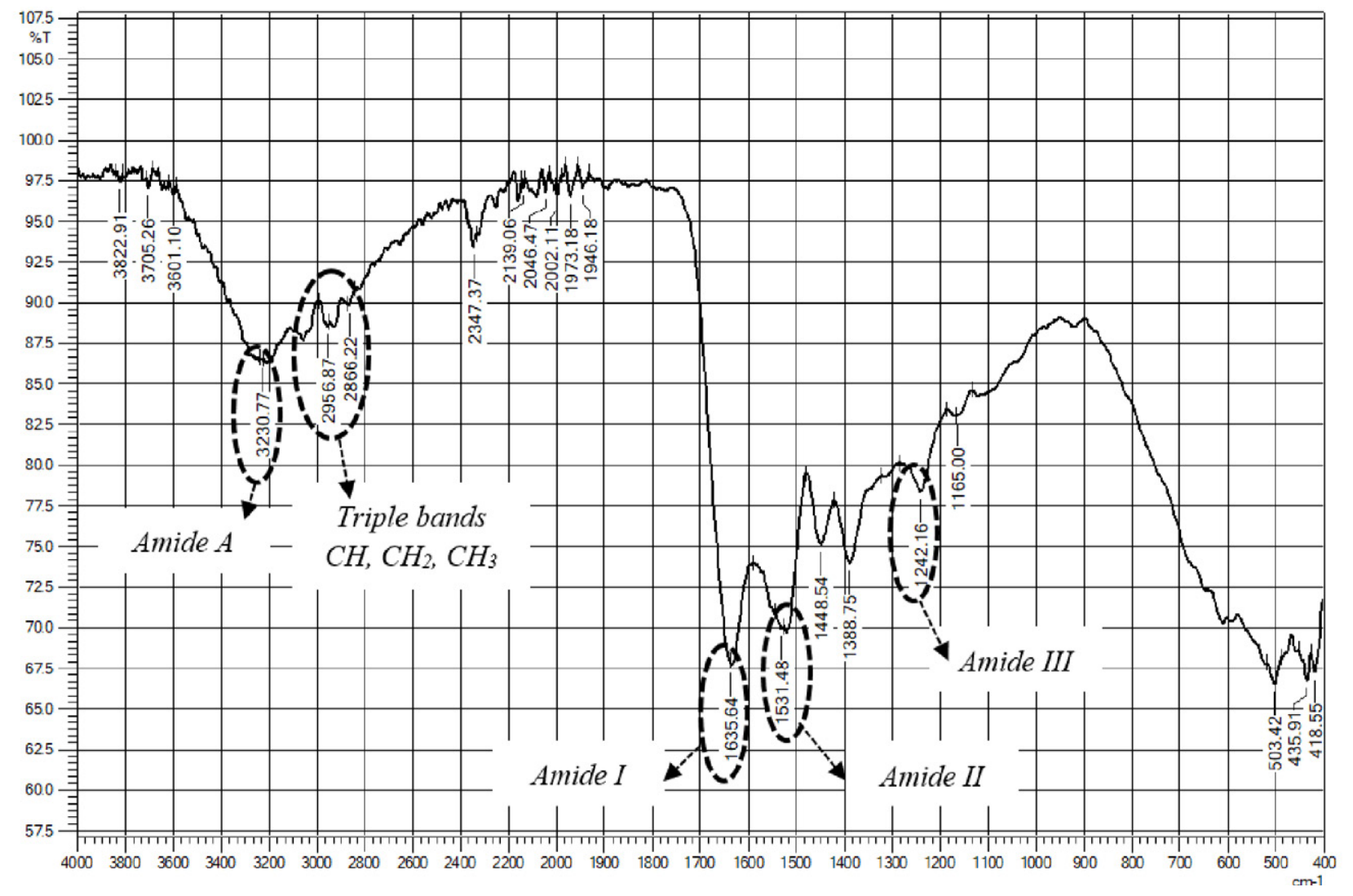

Figure 2. FTIR spectrum of keratin isolated from waste wool with SubCW at temperature of $180^{\circ} \mathrm{C}$ and a reaction time of $60 \mathrm{~min}$. 
(Figure 4) in Sephadex G-100 gel under the same conditions as the sample of extracted keratin (Figure 5).

The molecular weight distributions of the extracted proteins are shown in Table 4 and Figure 6. Figure 6 shows the SDS-PAGE electropherograms of wool proteins isolated by SubCW at different temperatures and reaction times.

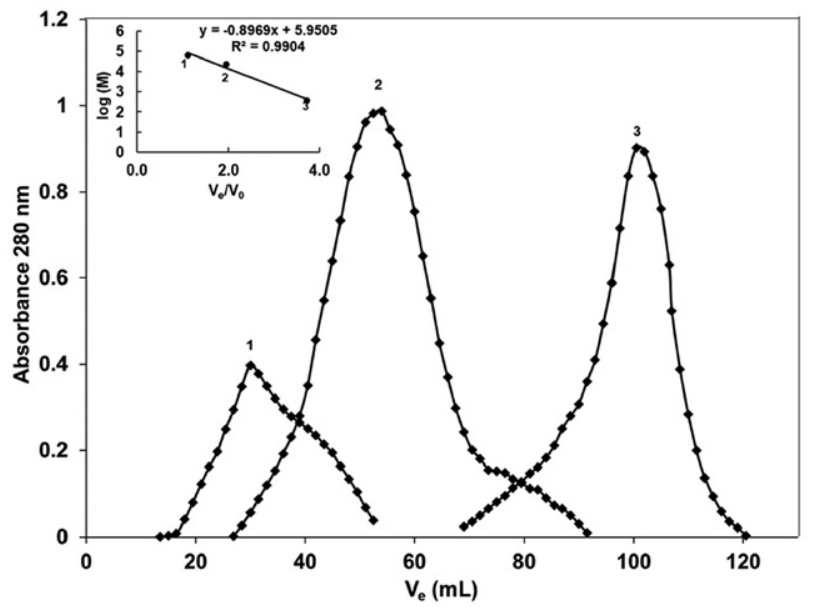

Figure 4. Gel permeation chromatography through Sephadex G-100 of standard proteins with known molecular weight: (1) BSA; (2) trypsin; (3) methylene blue.
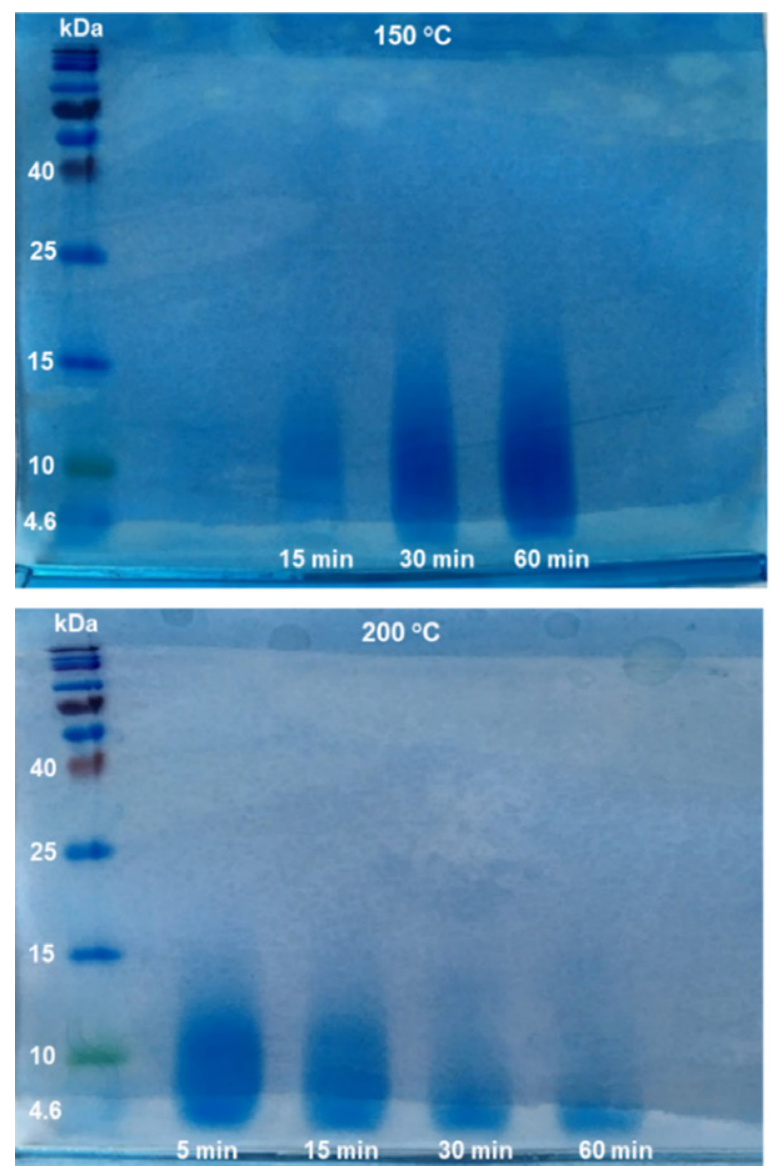

Figure 6. SDS-PAGE electrophoresis gels of isolated keratin.

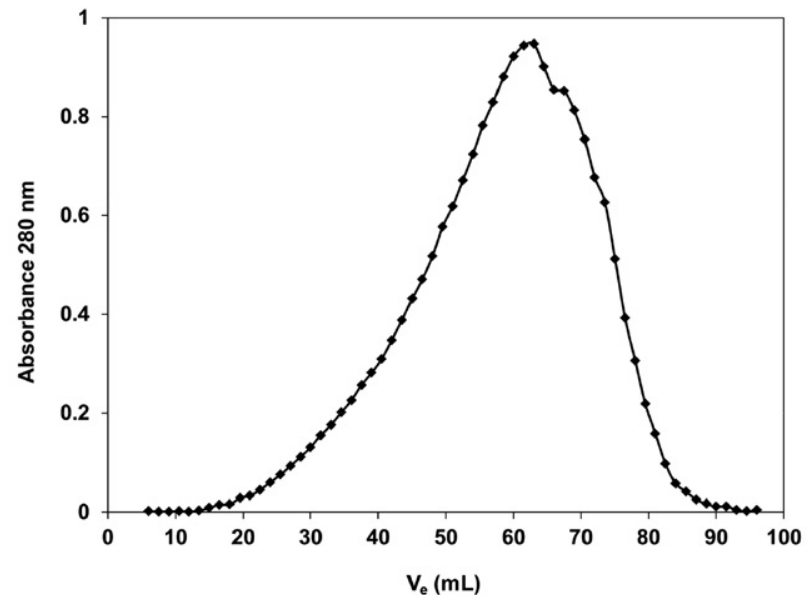

Figure 5. Gel permeation chromatography through Sephadex G-100 of isolated keratin at temperature of $180^{\circ} \mathrm{C}$ and time $60 \mathrm{~min}$.

Generally, the molecular weights of extracted proteins were quite low in all cases. A major protein fractions were in the range of $14 \mathrm{kDa}$ and $4 \mathrm{kDa}$.

Molecular weight distribution of isolated keratin at temperature of $150{ }^{\circ} \mathrm{C}$ and at time $5 \mathrm{~min}$ has not been determined, while the yield of keratin was only $1.7 \%$.

Table 4 shows, that molecular weight of extracted proteins decreased with increasing the temperature and
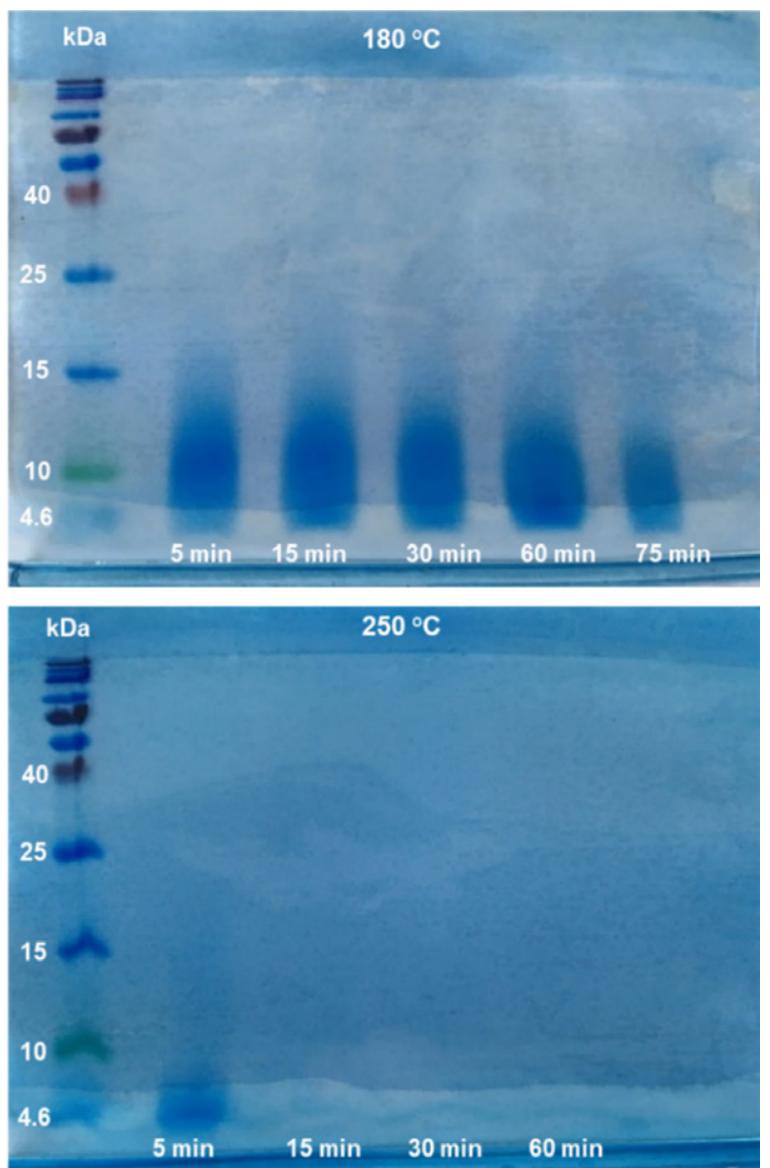
Table 4. Molecular weight of keratin.

\begin{tabular}{lccc}
\hline $\begin{array}{c}\text { Temperature } \\
\left({ }^{\circ} \mathbf{C}\right)\end{array}$ & $\begin{array}{c}\text { Reaction time } \\
(\mathbf{m i n})\end{array}$ & $\begin{array}{c}\text { Molecular weight of } \\
\text { keratin }(\mathbf{k D a}) \\
\text { (gel permeation } \\
\text { chromatography) }\end{array}$ & $\begin{array}{c}\text { Molecular weight of } \\
\text { keratin }(\mathbf{k D a}) \\
\text { (SDS-PAGE) }\end{array}$ \\
\hline 150 & 15 & 9.2 & $5-14.0$ \\
150 & 30 & 8.3 & $4.6-14.0$ \\
150 & 60 & 8.2 & $4.6-13.9$ \\
180 & 5 & 7.5 & $4.6-12.5$ \\
180 & 15 & 7.4 & $4.6-12.0$ \\
180 & 30 & 7.3 & $4.6-11.5$ \\
180 & 60 & 7.2 & $4.6-11.3$ \\
180 & 75 & 6.6 & $4.6-10.4$ \\
200 & 5 & 6.5 & $4.6-10.8$ \\
200 & 15 & 5.9 & $4.6-8.8$ \\
200 & 30 & 5.2 & $4.6-6.5$ \\
200 & 60 & 4.7 & $4.6-6.3$ \\
250 & 5 & 4.6 & $4.6-5.0$ \\
250 & 15 & 4.2 & $/$ \\
250 & 30 & 4.1 & $/$ \\
250 & 60 & 3.7 & $/$ \\
\hline
\end{tabular}

reaction time due to further degradation of long chain proteins to smaller molecules.

As can be seen from Figure 6, the clear major fraction band between $14-8 \mathrm{kDa}$ appeared after the hydrolysis of waste wool at $150^{\circ} \mathrm{C}$ for reaction time of 30 and $60 \mathrm{~min}$. Similar strong bands can be observed for products obtained at $180^{\circ} \mathrm{C}$ that indicate molecular weight between 13 $\mathrm{kDa}$ and $7 \mathrm{kDa}$ for all reaction times, while molecular weights at a higher temperature of $200^{\circ} \mathrm{C}$ are much lower, only between $10.8 \mathrm{kDa}$ and $5 \mathrm{kDa}$. In the case of $250^{\circ} \mathrm{C}$ the major protein fraction in the range from 5 to $4.6 \mathrm{kDa}$ results only for $5 \mathrm{~min}$ of reaction time, while at longer reaction times no bands were observed in the studied gels, which is a consequence of their degradation to very low molecular weight oligopeptides. ${ }^{8}$ Low molecular weights of keratin indicated that structure of keratin was significantly affected with the high temperature of the SubCW treatment (cleavage of peptide bonds).

Based on the results it can be concluded that the optimal temperatures for isolation of keratin molecules of high molecular weights by using SubCW would be $150^{\circ} \mathrm{C}$ or $180^{\circ} \mathrm{C}$, because at these two temperatures molecular weights of keratin obtained were the highest and were in the range of $14 \mathrm{kDa}$ to $4.6 \mathrm{kDa}$.

\section{4. Comparison of Molecular Weights of Keratin Extracted from Wool by Different Methods}

The molecular weight of keratin is influenced by the source from which the keratin is extracted due to structural differences, different content of sulphur and covalent intermolecular disulfide bonds, and by the method of keratin isolation. $8,9,24$
In Table 5 the molecular weights and yields of wool keratin obtained by different chemical methods reported in the literature are compared with the results obtained in the present work.

Table 5. Keratin molecular weights determined by SDS-PAGE electrophoresis and its yields isolated in different ways.

\begin{tabular}{lcc}
\hline Extraction method & $\begin{array}{c}\text { Molecular weight } \\
\text { of keratin (kDa) }\end{array}$ & $\begin{array}{c}\text { Yield } \\
\text { of keratin (\%) }\end{array}$ \\
\hline Oxidation $^{24}$ & $>40$ & 6 \\
Alkaline hydrolysis $^{24}$ & $<10$ & 25 \\
Superheated water $^{9}$ & $14-3$ & 31 \\
Sulfitolysis $^{24}$ & $60-40$ and $15-3.5$ & 41 \\
Ionic liquid $^{24}$ & $60-3.5$ & 51 \\
Reduction $^{24}$ & $55-40$ and 10-3.5 & 53 \\
$\mathrm{H}_{2} \mathrm{O}_{2}{ }^{8}$ & $36-6$ & 54 \\
SubCW & $\mathbf{1 4 - 4 . 0}$ & $\mathbf{9 0 . 3}$ \\
\hline
\end{tabular}

Shavandi and co-workers ${ }^{24}$ studied five different extraction methods of keratin from wool of merino ships. They used alkaline hydrolyses, reduction, oxidation, sulfitolysis and ionic liquid. For the reduction a solution of urea, sodium dodecyl sulphate and 2-mercaptoethanol was used, which gave the highest yield of keratin (53\%). By using the ionic liquid, the yield of keratin was $51 \%$. For sulfitolysis a solution of urea and sodium bisulfide was used and the yield of obtained keratin was $41 \%$. Alkaline hydrolysis was done in the presence of $2 \%$ solution of sodium hydroxide, where only $25 \%$ of keratin was isolated. The oxidation reaction, where the $2 \%$ solution of acetic acid was used, the lowest yield of keratin (6\%) was achieved. Keratin obtained by these various methods had different molecular weight and different physical-chemical proper- 
ties. ${ }^{24}$ In addition, keratin from wool and feathers was also extracted with different concentrations of hydrogen peroxide $\left(\mathrm{H}_{2} \mathrm{O}_{2}\right)$, where the highest yield of keratin from wool was obtained with $1 \mathrm{M} \mathrm{H}_{2} \mathrm{O}_{2}$ at $\mathrm{pH}=11$ and it was $72.6 \%{ }^{8}$

All chemical methods for keratin isolation presented in Table 5, except the oxidation method, gave keratin with molecular weights in a similar range as SubCW, which is between $14 \mathrm{kDa}$ and $4 \mathrm{kDa}$, however all the methods gave much lower yields as SubCW method, where the highest yield was $90.3 \%$. This is an important advantage over other extraction methods, which use additional organic solvents and harmful chemicals, which pollute and cause negative effects on our environment. The use of SubCW for isolation of keratin from wool is a much greener alternative.

\section{Conclusion}

Keratin isolation from waste wool was performed in a high pressure and high temperature batch reactor with Sub$\mathrm{CW}$ at temperatures of $150{ }^{\circ} \mathrm{C}-250^{\circ} \mathrm{C}$ and at different reaction time from $5 \mathrm{~min}$ to $75 \mathrm{~min}$. At the lowest temperature of isolation $\left(150^{\circ} \mathrm{C}\right)$ the yields of keratin were very low (between $1 \%$ and $26 \%$ ). The highest yield of keratin was achieved at $180^{\circ} \mathrm{C}$ and at a reaction time of $60 \mathrm{~min}$ and it was $90.3 \%$. At a temperature of $250^{\circ} \mathrm{C}$, the yield of keratin was lower than at a temperature $200^{\circ} \mathrm{C}$. The presence of keratin in reaction product was confirmed by FTIR spectroscopy. Molecular weights of extracted keratin were determined by gel permeation chromatography and SDS-PAGE electrophoresis. It was found that the molecular weight distribution of protein extracts was between $14 \mathrm{kDa}$ and $4 \mathrm{kDa}$. The molecular weight of protein decreased with increasing temperature, due to degradation of long chain keratin to oligomers and amino acids. The optimum operating conditions for keratin isolation from waste wool with SubCW are temperature $180^{\circ} \mathrm{C}$ and reaction time of $60 \mathrm{~min}$ where the yield of isolation was high and the molecular weight distribution of proteins was between 11.3 and $4.6 \mathrm{kDa}$.

The results of this study indicate that extraction of keratin from waste wool with SubCW-represents an important alternative to the conventional extraction processes and provide an important basis for further development of keratin based bioactive materials.

\section{Acknowledgements}

Special thanks to the Slovenian Research Agency (ARRS) for financial support of research programme group P2-0046: Separation processes and production design.

\section{References}

1. A. Shavandi, T. H. Silva, A. A. Bekhit and A. E.-D. A. Bekhit, Biomater. Sci., 2017, 5, 1699-1735. DOI:10.1039/C7BM00411G
2. P. Staroń, M. Banach and Z. Kowalski, Chemik, 2011, 65, 1019-1026.

3. S. Sharma, A. Gupta, S. Sharma and A. Gupta, Braz. Arch. Biol. Technol., 2016, 59, 1-14.

DOI:10.1590/1678-4324-2016150684

4. P. Mokrejs, O. Krejci, P. Svoboda and V. Vasek, Rasayan J. Chem., 2011, 4, 728-735.

5. J. M. Cardamone, J. Mol. Struct., 2010, 969, 97-105. DOI:10.1016/j.molstruc.2010.01.048

6. S. Zheng, Y. Nie, S. Zhang, X. Zhang and L. Wang, ACS Sustainable Chem. Eng., 2015, 3, 2925-2932.

DOI:10.1021/acssuschemeng.5b00895

7. J. G. Rouse and M. E. Van Dyke, Materials (Basel), 2010, 3, 999-1014. DOI:10.3390/ma3020999

8. B. Fernández-d'Arlas, Eur. Polym. J., 2018, 103, 187-197. DOI:10.1016/j.eurpolymj.2018.04.010

9. H. Rajabinejad, M. Zoccola, A. Patrucco, A. Montarsolo, G. Rovero and C. Tonin, Text. Res. J., 2018, 88, 2415-2424.

DOI:10.1177/0040517517723028

10. G. Zhu, X. Zhu, Z. Xiao, R. Zhou, N. Feng and Y. Niu, Biomass Conv. Bioref., 2015, 5, 309-320.

DOI:10.1007/s13399-014-0153-3

11. I. Pavlovič, Ž. Knez and M. Škerget, J. Agric. Food Chem., 2013, 61, 8003-8025. DOI:10.1021/jf401008a

12. Ž. Knez, M. K. Hrnčič, M. Čolnik and M. Škerget, J. Supercrit. Fluids, 2018, 133, 591-602. DOI:10.1016/j.supflu.2017.08.011

13. H. Qu, J.-H. Gong, X.-C. Tan, P.-Q. Yuan, Z.-M. Cheng and W.-K. Yuan, Chem. Eng. Sci., 2019, 195, 958-967.

DOI:10.1016/j.ces.2018.10.042

14. F. Ondze, O. Boutin, J.-C. Ruiz, J.-H. Ferrasse and F. Charton, Chem. Eng. Sci., 2015, 123, 350-358.

DOI:10.1016/j.ces.2014.11.026

15. X. Su, Y. Zhao, R. Zhang and J. Bi, Fuel Process. Technol., 2004, 85, 1249-1258. DOI:10.1016/j.fuproc.2003.11.044

16. H. Zhang, X. Su, D. Sun, R. Zhang and J. Bi, J. Fuel Chem. Technol., 2007, 35, 487-491. DOI:10.1016/S1872-5813(07)60030-9

17. A. Cata, M. Miclau, I. Ienascu, D. Ursu, C. Tanasie and M. N. Stefanuta, Rev. Roum. Chim, 2015, 60, 579-585.

18. M. Ravber, Ž. Knez and M. Škerget, J. Supercrit. Fluids, 2015, 104, 145-152. DOI:10.1016/j.supflu.2015.05.028

19. S. Jokić, T. Gagić, Ž. Knez, M. Banožić and M. Škerget, J. Supercrit. Fluids, 2019, 153, 104593.

DOI:10.1016/j.supflu.2019.104593

20. H. Cheng, X. Zhu, C. Zhu, J. Qian, N. Zhu, L. Zhao and J. Chen, Bioresour. Technol., 2008, 99, 3337-3341. DOI:10.1016/j.biortech.2007.08.024

21. C. Tonin, M. Zoccola, A. Aluigi, A. Varesano, A. Montarsolo, C. Vineis and F. Zimbardi, Biomacromolecules, 2006, 7, 34993504. DOI:10.1021/bm060597w

22. K. C. Duong-Ly and S. B. Gabelli, Meth. Enzymol., 2014, 541, 105-114. DOI:10.1016/B978-0-12-420119-4.00009-4

23. J. R. Whitaker, Anal. Chem., 1963, 35, 1950-1953. DOI:10.1021/ac60205a048

24. A. Shavandi, A. E.-D. A. Bekhit, A. Carne and A. Bekhit, J. Bioact. Compat. Polym., 2017, 32, 163-177.

DOI:10.1177/0883911516662069 


\section{Povzetek}

Pri temperaturah med 150 in $250{ }^{\circ} \mathrm{C}$ in reakcijskih časih med $5-75$ min smo izvedli subkritično vodno ekstrakcijo (SubCW) odpadne volne s ciljem pridobivanja keratina. Dobljene proteine prisotne v nastalih produktih smo potrdili $\mathrm{z}$ infrardečo spektroskopijo s Fourierovo Transformacijo (FTIR). Molekulsko maso ekstrahiranih proteinov smo določili z dvema tehnikama: poliakrilamidno elektroforezo $\mathrm{z}$ natrijevim dodecil sulfatom (SDS-PAGE) ter izključitveno kromatografijo. Rezultati so pokazali, da lahko s SubCW iz odpadne volne pridobimo keratin z zelo visokim izkoristkom, precej višjim kot z ostalimi kemijskimi metodami. Maksimalni izkoristek smo dosegli pri $180{ }^{\circ} \mathrm{C}$ in 60 minutah in je znašal $90.3 \%$. Porazdelitev velikosti proteinov ekstrahiranih iz odpadne volne je bila med $14 \mathrm{kDa}$ in $4 \mathrm{kDa}$, kar je primerljivo $\mathrm{z}$ rezultati ostalih kemijskih metod. 